1

\title{
A critical review of Shipbreaking literature reveals shortcomings in dimensions considered for sustainability
}

\author{
SM Mizanur Rahman ${ }^{\mathrm{a}}$ \\ ${ }^{a}$ University of Bordeaux, CNRS, Arts et Metiers Institute of Technology, Bordeaux INP, INRAE, I2M \\ Bordeaux, F-33400 Talence, France
}

\section{Abstract:}

The shipbreaking industry is located predominantly in South Asian countries, and dismantles end-of-life ships to meet national steel demand. There are charges that this industry exploits local environmental, economic and social conditions to boost profits. The majority of this previous research often draws from a single disciplinary point of view that ignores or downplays complexities and trade-offs, precluding realistic policy improvement. Here we review 110 shipbreaking papers published in international peer reviewed journals that are indexed in SCOPUS, Science Direct and Google Scholar. We found that to date, shipbreaking research revolves around the coastal contamination of end-of-life ships waste over many other topics, and lacks critical interdisciplinary studies that explain trade-offs between environmental, social and economic factors that would better inform policy formulations for improvement of worker safety and environmental conditions. We propose a Life Cycle Sustainability assessment (LCSA) framework that could incorporate these trade-offs in a single analysis. We hope this review guides future studies towards more comprehensive sustainability measurement of shipbreaking activities.

Keywords: shipbreaking; ship recycling; life cycle sustainability assessment; literature review; sustainability

\section{Introduction:}

The international shipbreaking industry provides a recycling service for commercial ships worldwide. More than $90 \%$ of end-of-life (EOL) ships are dismantled in five developing nations, a major shift from the historic dismantlement in developed countries due to higher environmental and safety costs that render these activities uncompetitive (Figure 1). Many of the developing nations which now host the ship recycling industry benefit as few have native sources of steel and other recycled materials. For example, with annual economic transactions of about 1.5 billion dollars, the scrap steel meets $60-70 \%$ of local steel demand in Bangladesh (Rahman and Mayer 2015). The ship demolition activities represent a critical lifeline for construction industries across the country, involving about 50,000 direct and 100,000 indirect employment opportunities in Bangladesh (Gregson et al. 2012, Sujauddin et al. 2014, Rahman and Mayer 2015). 

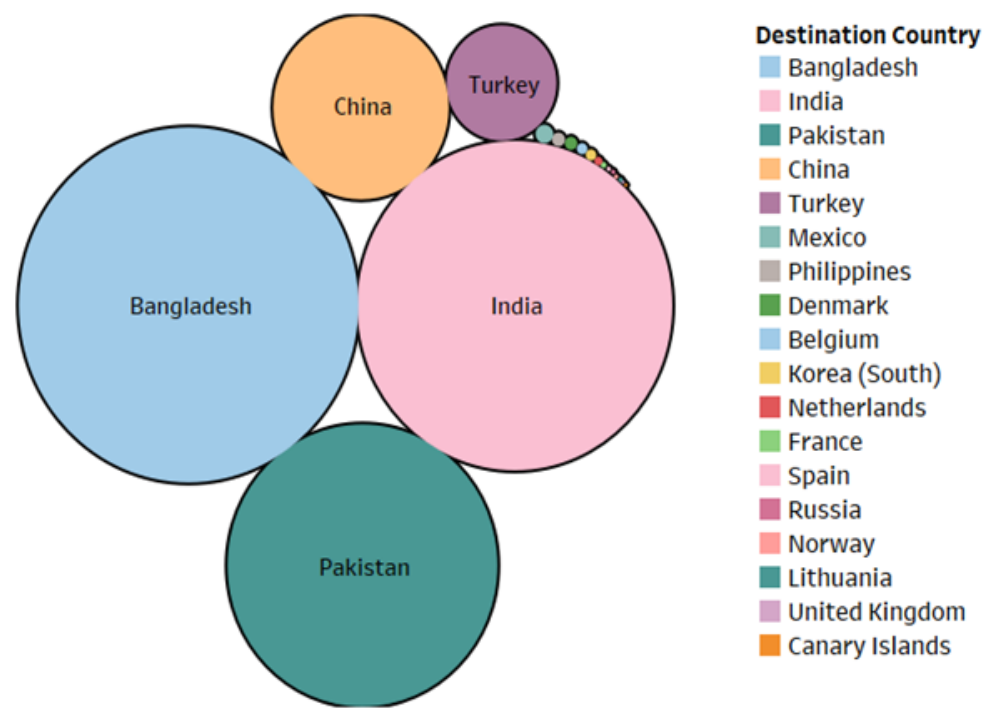

Figure 1: Global shipbreaking activities in 2016: data from NGO Shipbreaking Platform, 2017

The shipbreaking industry currently faces a large number of social, economic and policy challenges (Cairns 2007, Neser et al. 2008, Hillier 2009, Demaria 2010, Gregson et al. 2012, Cairns 2014, Devault et al. 2016, Jain et al. 2016, Rahman and Mayer 2016). Stakeholders who influence or are directly impacted by the positive and negative sustainability aspects of the current state of affairs include yard owners, NGOs (both national and international), shipowners and brokers, international organizations and policy conventions (such as treaties), national governmental agencies, academics, local communities, and the workers. Broadly speaking, ship-owners and yard-owners have an interest in securing a positive profit margin (Jain et al. 2016, Schoyen et al. 2017), while NGOs and researchers mainly focus on poor working conditions and negative environmental effects (Anderson 2001, Neser et al. 2008, Hossain and Islam 2006, Reddy et al. 2003, NGO Shipbreaking Platform 2017). International and national policy makers tend to formulate policies that attempt a compromise between economic demands and environmental and social impacts, however quite a few stakeholders view these as ineffective in improving the status quo (Mikelis 2008, Cairns 2014, Rahman and Mayer 2016). National policy implementers in government utilize least impact strategies to deal with international policies and ground level realities, while international policies struggle to enforce a "polluter pays principle" with the existing system of privatized profits and socialized costs (Rahman and Mayer 2016). Given such a contrasting array of views, identifying solutions that will improve multiple dimensions of the shipbreaking industry remains a significant challenge for the stakeholders, leaving barriers to sustainability intact (Cairns 2007; Cairns 2014).

But what would a sustainable ship breaking industry look like? Academic and professional researchers play a role in identifying sustainability standards by documenting the current state of the industry in terms of its environmental, social, and economic impacts. And since these dimensions are highly connected, interdisciplinary and transdisciplinary research is needed to investigate issues that lie in the interface of sustainability dimensions. However, given the slow pace of improvement in sustainability indicators and targets for the shipbreaking 
industry, we seek to identify gaps in knowledge in the scientific literature that may be contributing to lack of progress. We hypothesize that the enduring sustainability issues in the industry are driven by a single-discipline or single-dimension approach to knowledge generation by researchers and other stakeholders. Furthermore, we hypothesize that this exclusionary approach makes it difficult to develop a complementary policy environment where policies focused on one dimension do not work against those formulated in others. This review thus deals with this research question: where are the gaps within and between environmental, social and economic spheres of the shipbreaking industry in Southeast Asia?

A paradigm shift occurs from environmental sustainability to triple bottom line sustainability that acknowledges that a balance must be maintained among environmental, economic and social wellbeing (Finkbeiner et al. 2010). Systematic assessment of these three dimensions is addressed in LCSA literature through combining environmental life cycle assessment (eLCA), life cycle costing (LCC) and social life cycle assessment (SLCA). Life cycle assessment is unique from other assessment tools in at least two aspects: 1) it considers all phases of the life cycle of a product, from the extraction and processing of raw materials, to manufacturing of the products, to use and disposal; and 2) it combines and estimates environmental, social and economic aspects within a functional unit and unified system boundary, allowing comparability of the performance of the product among the life cycle phases within and across dimensions (Weidema, 2006, Kloepffer 2008, Traverso et al. 2012). Related to the shipbreaking industry, the application of LCSA can identify questions that require cross disciplinary investigation such as: social and economic (the cost and equity of improved occupational safety); environment and economic (costs versus benefits of proper waste management), environment and social (the impact on community wellbeing of coastal pollution). Here we adopt a systematic review technique to identify existing research patterns and offer future research directions for advancing shipbreaking knowledge. A review paper identifies long-standing research deficits and creates a framework for new research, leading to reorganization of research areas (Webstar and Watson 2002). Our work complements that of Hossain et al (2016), which reviews pollution assessment in Bangladesh but from a predominantly environmental perspective.

\section{Research Methodology:}

We follow Suring and Muller's (2008) two objectives for reviewing literature: 1) summarize the major patterns, themes and issues; and 2) identify research gaps and propose a future research focus. Mayring (2003) describes a four-step procedure for a review paper that we also use here: 1) Study scope and literature search, 2) Descriptive analysis, 3) Category selection and 4) Material evaluation. For the latter two tasks, we used NVivo qualitative data analysis software to guide subjective theme selection and content analysis through the "text search query", "most frequent word search" and "coding” tools (NVivo 2017).

\subsection{Study scope and literature search:}

The scope was limited to peer reviewed scientific articles and conference papers, with accessible full text in English, that contained "shipbreaking" or "ship recycling" in their titles and/or in the abstract. The University of Technology of Troyes has access to a wide number of journals, and access to full articles of identified papers was $86 / 94 * 100=91 \%$ for this 
study. The boundary selection excluded research on shipbreaking in other languages, as well as reports and news articles.

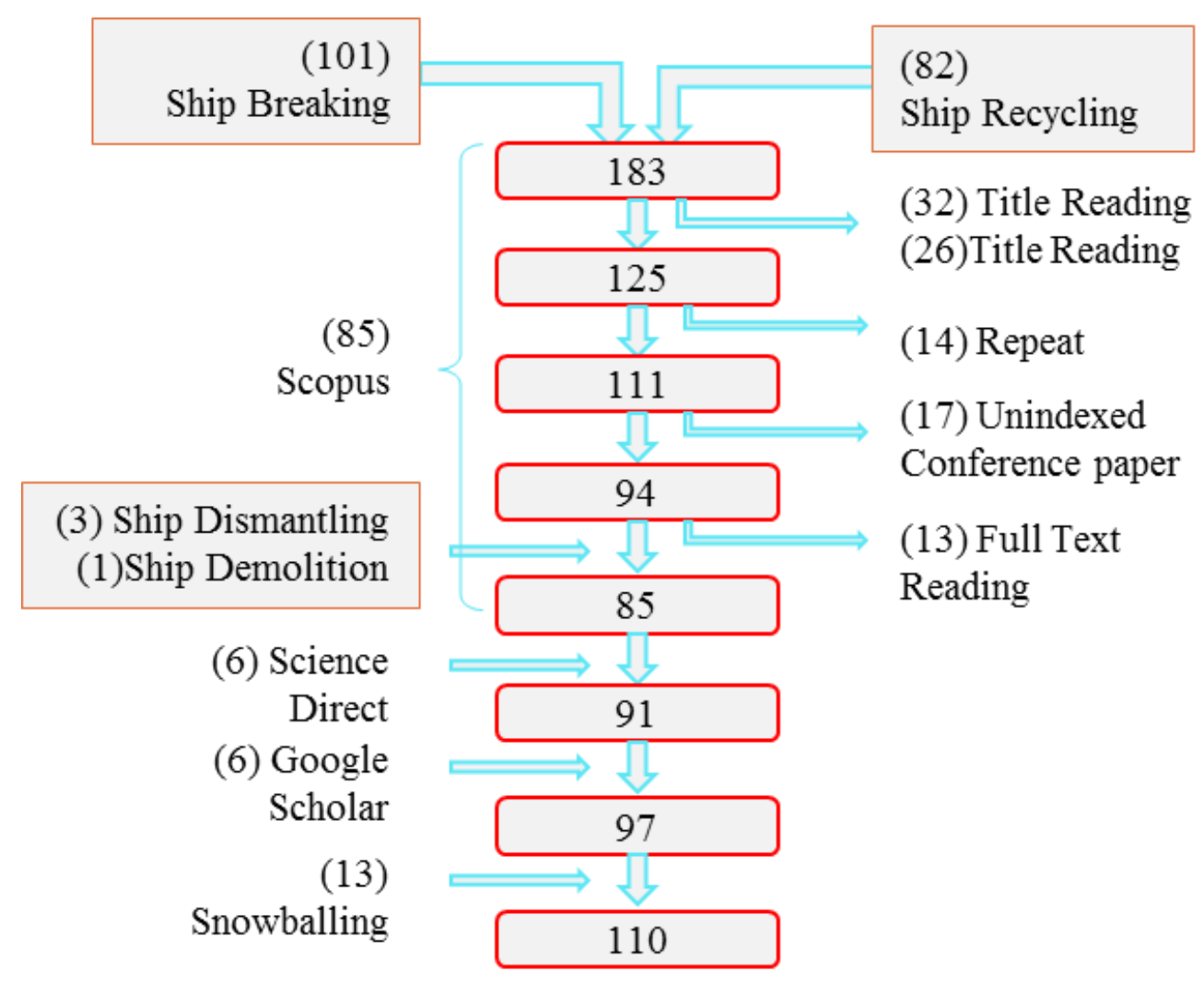

Figure 2 : Article selection process and database sources. The rectangular box with texts and numbers denotes the keywords used to search the literature and the number of search results.

This paper utilized Scopus, Science Direct and Google Scholar databases to identify potential papers. Scopus is the largest abstract and citation database of peer reviewed literature, with over 60 million records going back as far as 1823. The database has enabling tools to track, analyse and visualize research (Scopus 2017). The keywords used were "Ship breaking" and "Ship recycling" in "All article title, Abstract and Keyword search". This returned 101 results for "Ship Breaking" and 82 results for "Ship Recycling" searched in June 2017. The change of key words to "Shipbreaking" "Shiprecycling" returned 61 and zero papers, respectively, with no new results in the latter search. (Figure 2).

Of the 183 results, 125 articles were initially included based on an expanded set of keywords: "Shipbreaking" and "Ship recycling". A few additional articles were added based on our familiarity of the content of the articles that discussed issues regarding shipbreaking, but may not have made use of these words in the title or abstract. In the next round, 14 articles that appeared in both searches were excluded. In the third round, based on a full text reading, another 17 were excluded of which 14 articles were conference papers that were not indexed in an internationally accepted scientific database. At this point, we added two more keywords: "Ship Dismantling" and "Ship demolition", resulting in four more articles added to the list, demonstrating the inclusiveness of the search (Oxman 1993). Our main concern with the 
Scopus results was that this search did not return any studies on Pakistan shipbreaking, and returned only two studies on China, which are the fourth and third major shipbreaking nations after Bangladesh and India respectively.

To validate and ensure the exhaustive capture of the shipbreaking literature, we also ran a literature search in Science Direct using the same key words. "Ship breaking" and "Ship recycling" keywords returned 356 and 97 articles respectively. The change of key words to "Shipbreaking" and "Shiprecycling" returned 96 and 3 results respectively. We considered key words for "Ship breaking" and "Ship recycling" in order to ensure the maximum possible capture of published literature. Out of these 356 papers, we identified an additional six papers that were not covered in the Scopus database through title and abstract reading. The decreasing returns with respect to additional articles not identified in Scopus suggested we were nearing an exhaustive list of shipbreaking literature. This Science Direct search returned three articles on India, two on China, one that was global in scope, and none from Pakistan.

We then used Google scholar in a targeted search for "Shipbreaking in Pakistan" and "Shipbreaking in China", which produced 6 publications on Pakistan and 8 on China, including reports published in collaboration with NGOs. These publications are not often indexed in international databases, and thus may be the reason they were missed in the previous two searches. Finally, we scanned the cited references of the papers. An additional 13 articles were identified from references sections that met our search criteria. Thus, a total of 110 articles are included in this review paper (Figure 2).

The papers were categorized into disciplinary categories. Environmental Science categories included papers that investigated pollution, such as applying laboratory-based experiments through the collection of water samples to identify pollutant contents. Environmental Engineering disciplines represented methods such as material flow analysis and engineering assessments, seeking to optimize the design aspect of shipbreaking. Safety management deals with exposure assessment and working conditions. Social Science disciplines broadly engaged in world system, policy development and cultural contexts. Papers that discussed more than one dimension were placed into interdisciplinary categories, however those papers generally lacked methodologies that could explain complex trade-offs. The articles were also divided in terms of the dimension of sustainability covered. Environmental and economic dimensions were straightforward with explicit content in the paper. However, the social dimension included diverse themes including policy, culture, risk assessment and working conditions. When there was more than one dimension discussed in a paper, we included it in a "sustainability" dimension.

\section{Results}

\subsection{Papers by time, discipline and country}

Descriptive analysis was performed based on the distribution of scientific articles across time, discipline, and country. Figure 3 shows the rapidly increasing number of papers published since 2003. The figure also shows the absence of shipbreaking research from 1990 to 2000. This is probably due to the transition in the shipbreaking industry at that time, with a geographic shift in activities from developed to developing countries. The earlier publications demonstrated the consequences of occupational exposure of the workers, contributing to the 
cessation of those jobs in developed countries and the decline in the attention paid by researchers. The reappearance of the topic demonstrates a time lag between the actual start-up of the work in developing countries and the visible consequences of the work on the environment and workers. For example, shipbreaking in Bangladesh started in the early 1980s, and literature on the issue started to appear two decades later (Figure 3).

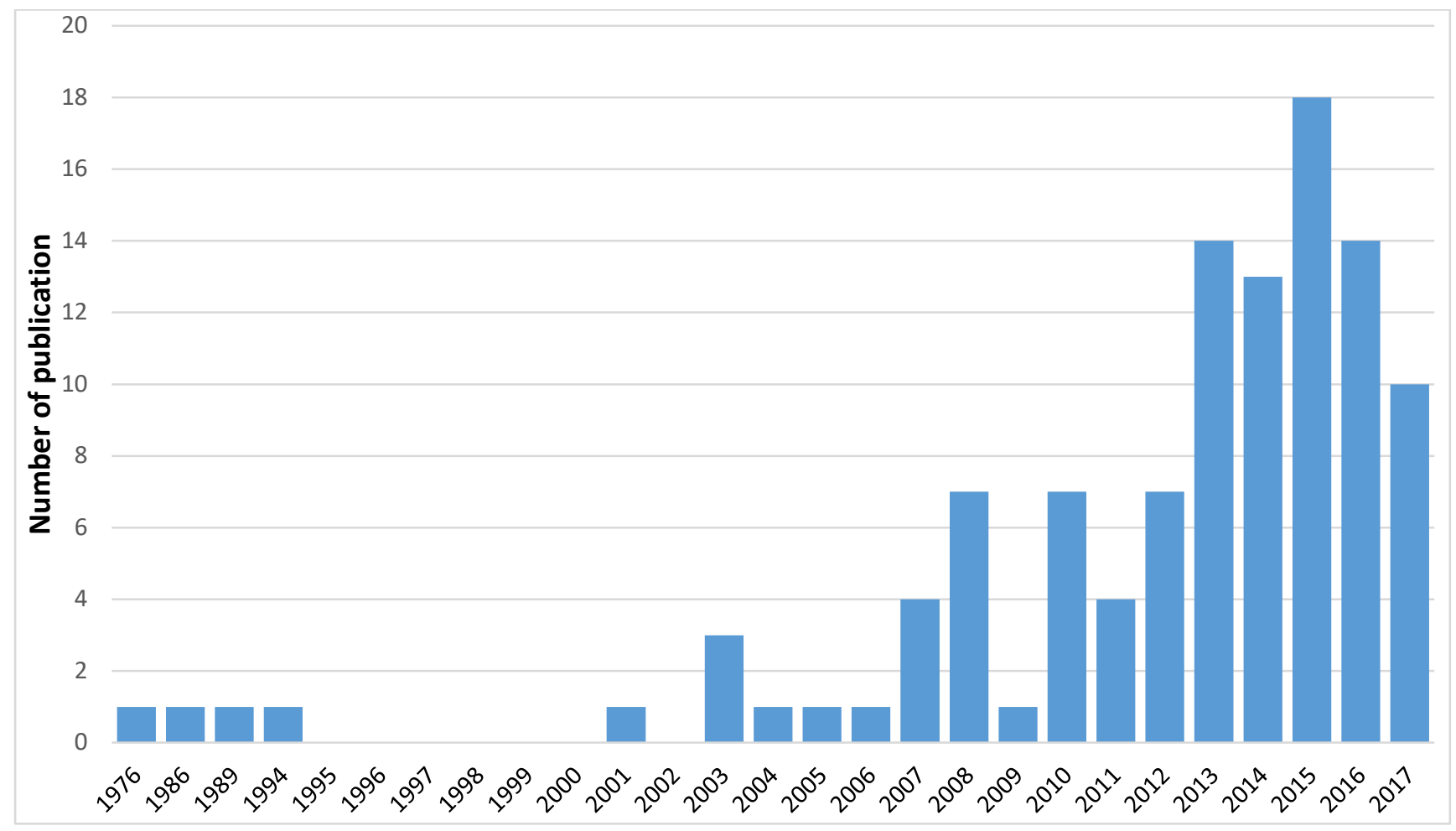

Figure 3: Shipbreaking literature published by year. 

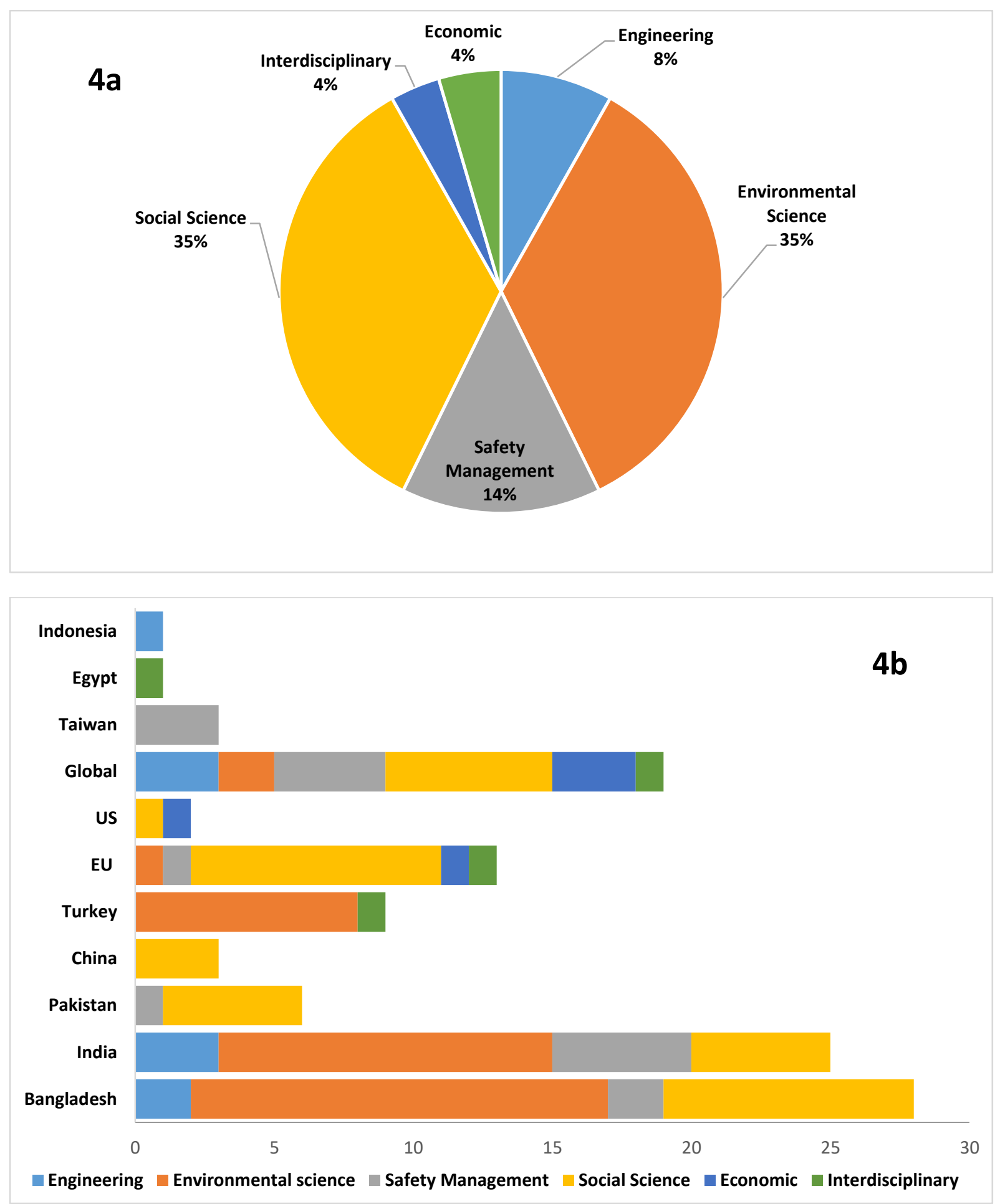

Figure 4: Shipbreaking research by discipline (a) and nation (b).

191 Figure 4a illustrates the disciplinary representation of the shipbreaking research. Social

192 Science studies (excluding economic analyses), including a substantial number of qualitative 193 ethnographic studies, represent the largest category of focus, accounting for $35 \%$ of all 194 studies. Environmental Science studies also represented 35\% of the total number of papers, 195 while Environmental Engineering accounted for only $8 \%$ of literature. Safety Management 
shares $14 \%$, while Economic discipline shares only 4\%. Studies that encompassed more than one disciplinary boundaries were few; they represented less than five percent of the studies on SBI.

Figure $4 \mathrm{~b}$ further breaks down the disciplinary boundaries by country. India and Bangladesh have had a similar number of Environmental Science, Social Science and Environmental Engineering studies, with pollution assessment as a primary focus of most of the publications. Studies in Turkey exclusively focused on pollution assessment. Papers that looked at the global industry as a whole had the most publications from the Social Sciences, and none from Environmental Science, which we consider to be a major gap in the field given the pollution implications of avoided mining activities and the global trade in recycled metals. Generally speaking, the total number of papers by country was correlated to the relative size of each country's shipbreaking activities (Figure 5). Bangladesh and India receive the highest number of EOL ships and also receive the most attention, although the SBI in Pakistan and China seems to be getting less attention than the size of their activities warrant.

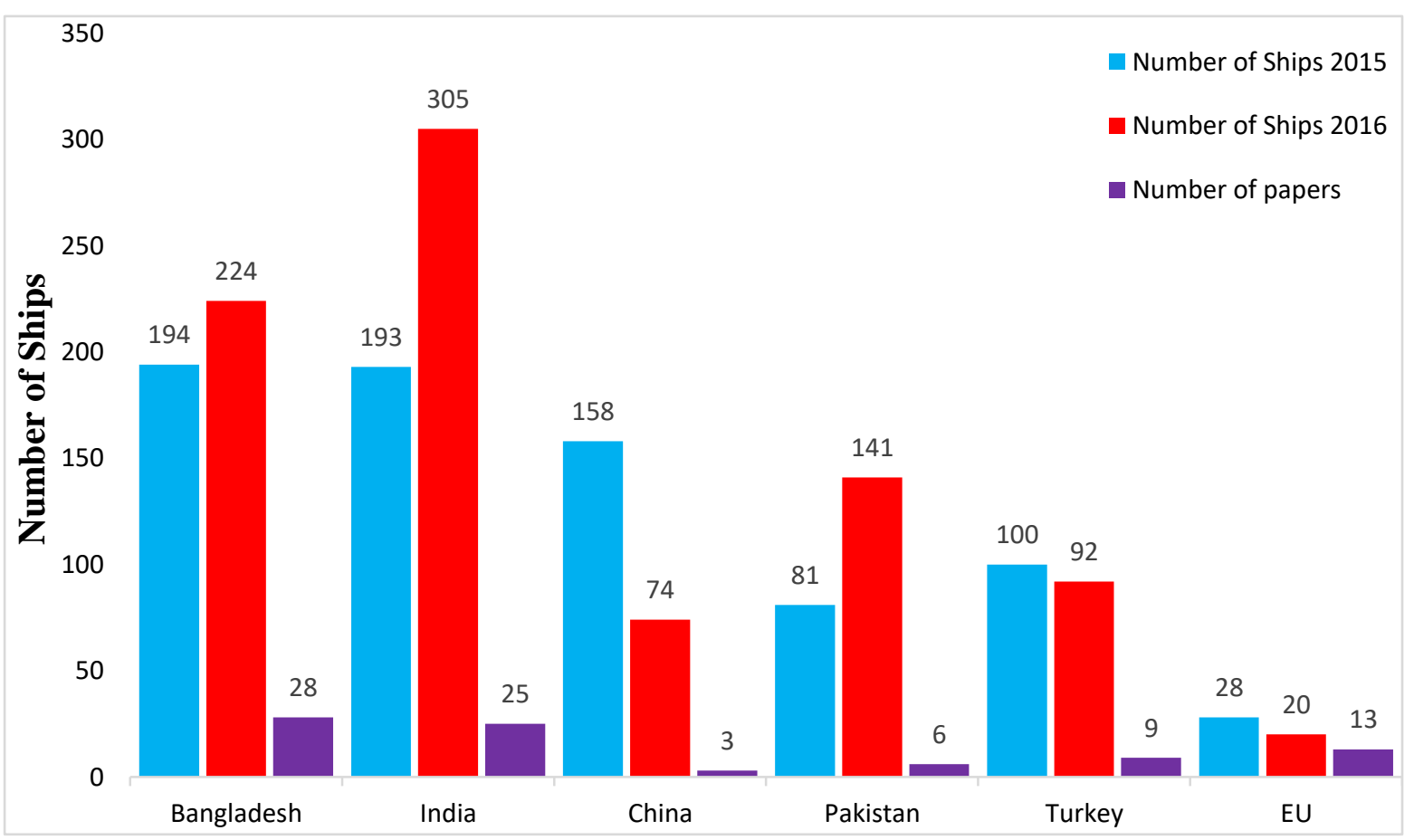

Figure 5: The number of end-of-life ships dismantled in 2015 and 2016 and the number of peer reviewed papers published up to June 2017 by country. Shipbreaking data from the NGO shipbreaking platform. The number of publications on the US (2), Global scale (18) and other countries (5) that are not shipbreaking countries are not included in this figure.

\subsection{Dimensions of Sustainable development:}

There were only 4 publications which discussed more than one dimension and were categorized as interdisciplinary (Neser et al. 2008, Choi et al. 2016, Devault et al. 2016, 
222 Welaya et al. 2012). Likewise, a critical shortage of papers on economic conditions was 223 evident; only 5 publications published out of 110 (McKenney 1994, Knapp et al. 2008, 224 Kagkarakis et al. 2016, Kusumaningdyah et al. 2013, Schoyen et al. 2017) (Figure 6).

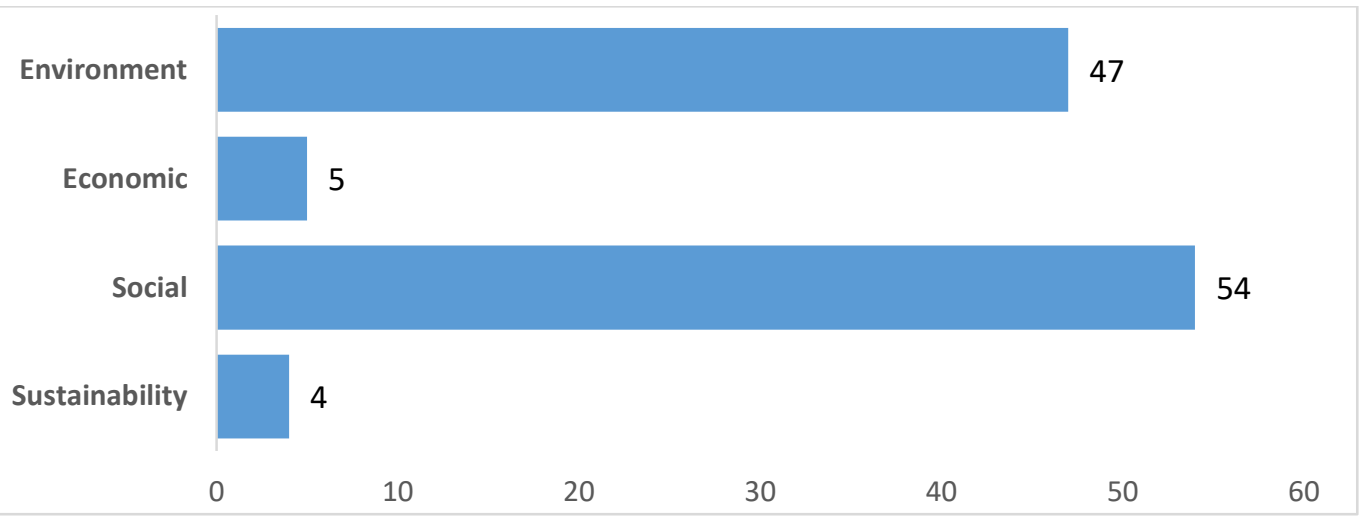

227 Figure 6: Dimensions of sustainability addressed in selected papers.

228

229

230

\subsection{Review structure:}

We used a concept centric review style using a concept matrix to proceed with the themes analysis (Webster and Watson 2008). We developed themes based on the major set of commonly-used words (Figure 7). Each paper was categorized in at least one of the themes with a maximum of two themes for each paper. Within each disciplinary category (Environmental Science, Environmental Engineering, Safety Management, Economics, Social Sciences), multiple subthemes emerged (Table 1).

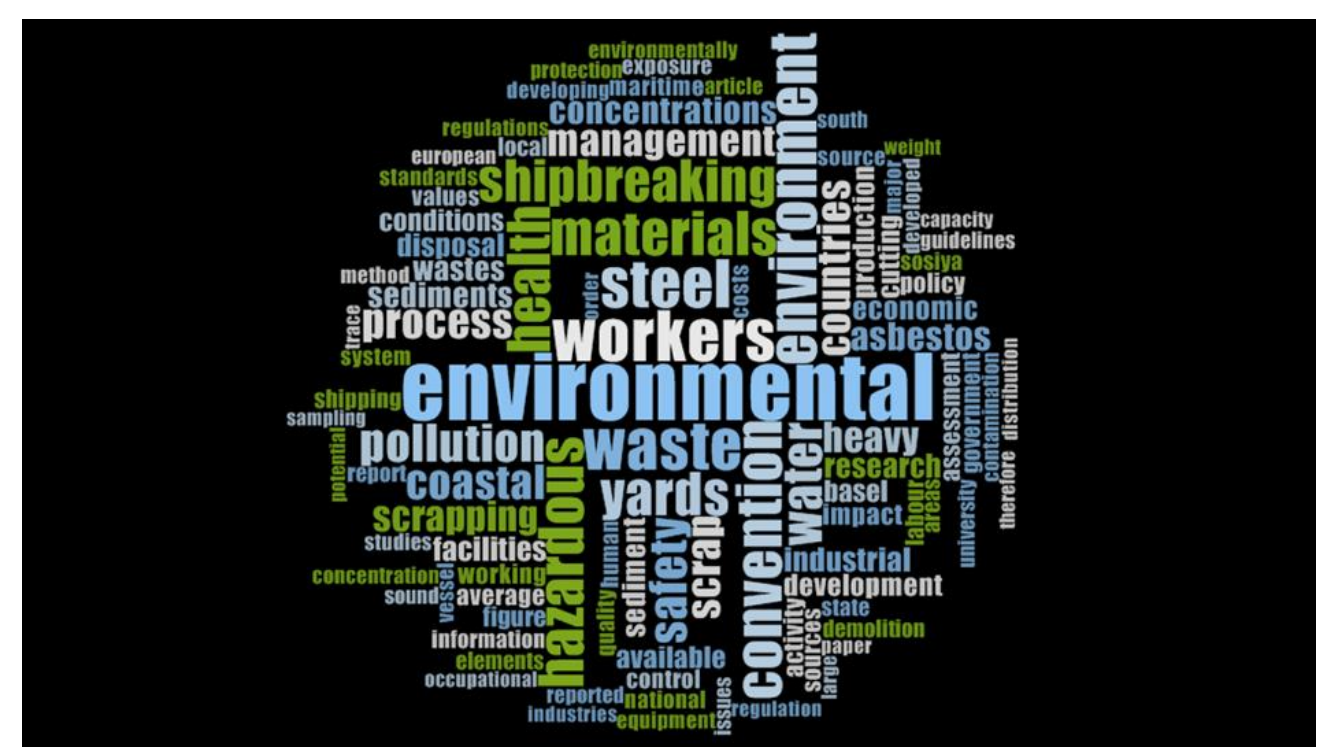

Figure 7 : Most pronounced concepts identified in N-Vivo from the selected articles. 
243 Table 1. Disciplinary categories and subthemes used to classify papers.

244

245

\begin{tabular}{ll}
\hline Disciplinary categories and subthemes \\
\hline ES & Environmental Science \\
\hline ES1 & Waste quantification \\
ES2 & Pollution assessment \\
ES3 & Source apportionment \\
ES4 & Impact assessment \\
\hline EE & Environmental Engineering \\
\hline EE1 & Design for recycling \\
EE2 & Best waste management practices \\
\hline SM & Safety Management \\
\hline SM1 & Exposure assessment \\
SM2 & Worker and working rights \\
& \\
\hline SS & Social Science \\
\hline SS1 & Justice and world system \\
SS2 & Policy challenges \\
SS4 & Recycling networks as cultural \\
\hline Econ & Economics of shipbreaking \\
\hline
\end{tabular}



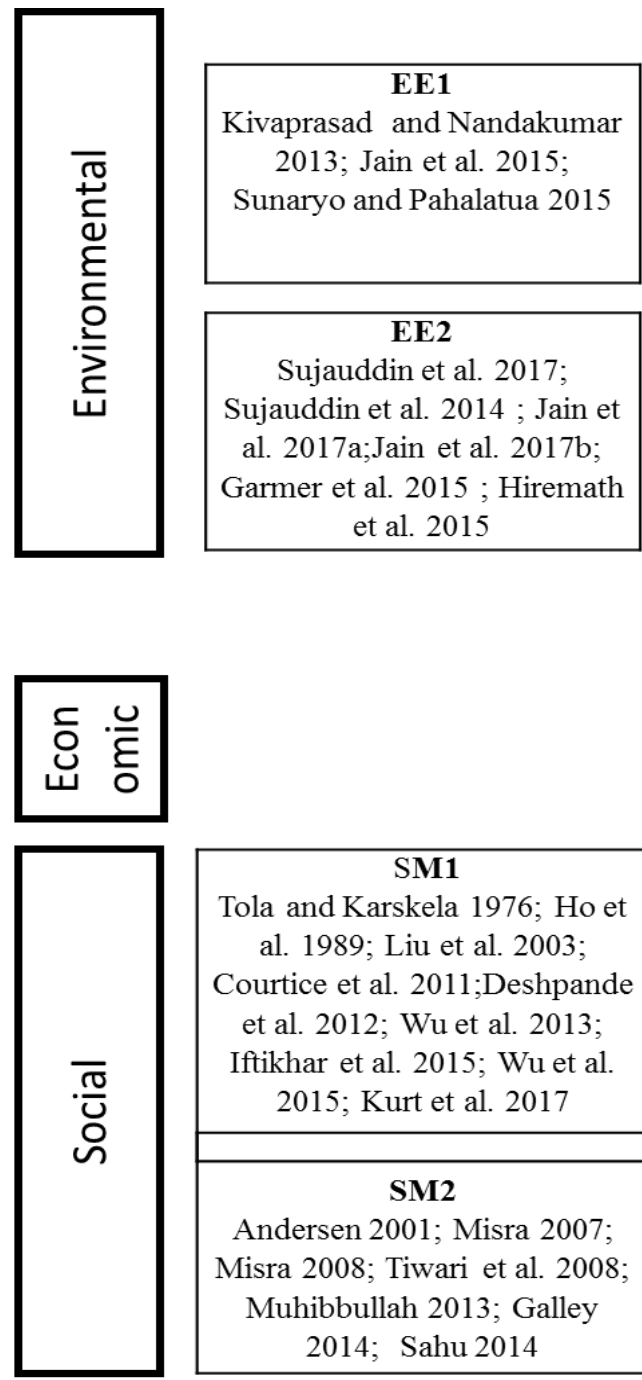
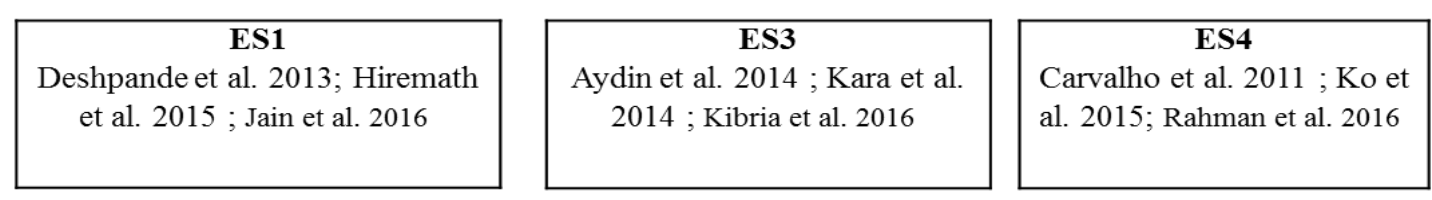

ES2

Islam and Hossain 1986; Khan and Khan 2003; Reddy et al. 2003 ; Reddy et al. 2005 ; Reddy et al. 2004 ; Reddy et al. 2006; Basha et al. 2007 ; Neşer et al. 2012 ; Neşer et al. 2012 ; Abdullah et al. 2013; Hasan et al. 2013a; Hasan et al. 2013b; Kacar and Kocyigit 2013; Aktaruzzaman et al. 2014; Siddiquee et al. 2014; Fakhruddin et al. 2015; Kara et al. 2015a; Kara et al. 2015b; Nøst et al. 2015;

Sharifuzzaman et al. 2015; Hossain et al. 2016; Habibullah-Al-Mamun et al. 2016; Khan et al. 2017; Odabasi et al. 2017 ; Bioremidiation

Patel et al. 2012; Patel et al. 2013; Patel et al. 2014; Patel et al. 2015; Shah et al. 2015

\begin{tabular}{|c|}
\hline Interdisciplinary \\
Neşer et al. 2008; Welaya et al. 2012; Choi et al. 2016; Devault et al. 2016 \\
\hline $\begin{array}{c}\text { Econ } \\
\text { McKenney 1994; Knapp et al. } 2008 \text {; Kusumaningdyah, et al. 2013; Kagkarakis et al. } \\
\text { 2016; Schøyen et al. 2017 }\end{array}$
\end{tabular}

\begin{tabular}{|c|c|}
\hline $\begin{array}{c}\text { SS1 } \\
\text { Cairns 2007; Sonak et al. 2008; Demaria 2010; } \\
\text { Cairns 2014; Reddy 2014; Demaria 2015; }\end{array}$ & $\begin{array}{c}\text { SS4 } \\
\text { Hillier 2009; Gregson et al. 2010; Gregson et al. } \\
\text { 2010; Gregson 2011; Gregson et al. 2012; Crang } \\
\text { et al. 2013; Gregson et al. 2013; Rahman and } \\
\text { Mayer 2015; Gregson et al. 2016 }\end{array}$ \\
\hline & SS2
\end{tabular}

Rousmaniere and Raj 2007; Kaiser 2008; Mikelis 2008; Chang et al. 2010; Matz-Lück 2010, Puthucherril 2010; Saraf et al. 2010 ; Radonja and Jugović 2011; Garud 2012; Ahmed and Siddiqui 2013; Iqbal and Heidegger 2013 ; Alam and Faruque 2014; Yujuico 2014; Zhao and Chang 2014, Karim 2015; Alcaidea et al. 2016; Memon and Zarar 2016, Moncayo 2016; Rahman and Mayer 2016, ZafarUllah et al. 2016, Alcaidea et al. 2017; Du et al. 2017; Khandaker 2017;

Figure 8. Subject-wise classification of the reviewed articles. The left bold boundary denotes the dimension wise category. MS category is considered as the Social dimension category for evaluation purpose but are analyzed separately because of its significant representation in the literature. 


\section{Discussion:}

\subsection{Environment:}

\subsubsection{Waste quantification on board:}

Actual waste content and the proportion that is released into the environment are two important environmental impacts of EOL ship dismantling. Few studies have focused on estimating the actual waste content in the ships, with uncertainty and variability arising from ship type and age (Carvalho et al. 2011, Hiremath et al. 2015, Rahman et al. 2016, Jain et al. 2016). Actual waste content based on different types of ships was estimated as 0-3\% by weight in Carvalho et al. (2011) based on five type of ships, 2\% in Jain et al. (2016) based on a bulk carrier, 5-10\% in Demaria (2010) and 6\% in Sujauddin et al. (2015). Structural organization, material use and distribution, in addition to ship type, make it difficult to obtain reliable and consistent data of waste content and the associated impact (Carvalho et al. 2011, Du et al. 2012, Jain et al. 2016). Waste content models by ship type and age may be developed in the future (Hiremath et al. 2016, Jain et al. 2016).

The consideration of content as waste also depends on cultural, institutional and market conditions (Gregson et al. 2010, Rahman and Mayer 2015), thus requiring the incorporation of additional social variables in waste quantification modelling. This area of on board waste content deserves more research attention in order to generate reliable waste data, and to model actual waste discharge to the environment in shipbreaking countries.

\subsubsection{Pollutant assessment in shipbreaking areas:}

A total of 24 pollution assessment studies of the 38 Environmental Science papers revealed a strong research focus on identifying pollution potentials of shipbreaking. The studies differ in terms of type and nature of pollutants, affected areas and seasons. Most of the literature estimated the concentration of common water and air pollutants such as oil, heavy metals, asbestos and persistent organic pollutants, demonstrating concentration levels above safety threshold values in India (Reddy et al. 2003, 2004 and 2005 Patel et al. 2012, Patel et al. 2013, Patel et al. 2014, Jumaila et al. 2015, Shah et al. 2015), in Bangladesh (Siddiquee et al. 2009, Sharifuzzaman et al. 2016, Khan et al. 2017, Hasan et al. 2013, Khan and Khan 2003, Hasan et al. 2013, Islam and Hossain 1986, Abdullah et al. 2013, Aktaruzzaman et al. 2014, Hossain et al. 2016, Kibria et al. 2016), and in Turkey ( Neser et al. 2008, 2012a, 2012b, Kacar and Kocyigit 2013). This high level of pollution threatens ecosystems and local communities. However, pollution assessment studies can be more precise if the diverse sources of pollutant release are taken into account in discussing pollution from shipbreaking (Neser et al. 2008).

The major attempts to identify and separate sources of pollutants diagnosed in coastal soil, water and air were taken by Aydin et al. (2014) and Kara et al. (2014). They used multiple site analysis and principal component analysis to understand the level of pollutants emitted from each of multiple sites: biomass and coal combustion $40 \%$ (residential and industrial coal combustion), iron and steel production (27\%), unburned crude oil and petroleum products $(27 \%)$, diesel (3\%) and gasoline exhaust emissions (3\%; Ayedin et al. 2015). In Bangladesh, Kibira et al. (2016) conducted a pollution assessment on 7 heavy 
metals in three regions in Bangladesh: Dhaka (3 sites), Chittagong (4 sites) and Khulna (2 sites). The study found that the sites near the shipbreaking industry yield less impact compared to the other sites where both shipbreaking and other industries exist. The highest impact was observed in Dhaka (the capital of the country), with five out of seven heavy metals measured beyond safety thresholds. This source-specific pollutant estimation indicates a nuanced understanding of shipbreaking impacts.

\subsubsection{Impact assessment}

Applying life cycle assessment methods in Bangladesh shipbreaking, Rahman et al. (2016) found that the core activities that happen during ship dismantling in the yards record less environmental damage compared to the other stages that occur outside of the yards, such as rerolling of scrap metals. In addition, the study modelled waste discharge to coastal waters based on interview data and secondary data and found that the waste impact in three damage categories comprise only $0.3 \%$ of the total impact. The results of this study conformed to findings of Ayedin et al. (2014), Kara et al. (2015a) and Kara et al. (2015b), necessitating changes of research direction towards sophisticated impact assessment methods that can model waste discharge and its impact on ecosystems. Although the waste content, waste release and impact mechanism within the ecosystem greatly varies based on ship type, size and age, these studies provide evidence that environmental pollution studies require inclusion of source apportionment research and actual waste content and release of EOL ships.

\subsection{Engineering:}

\subsubsection{Design for Environment:}

Three articles discussed ship design for improved recycling and avoided environmental pollutants and hazardous materials. Shivaprashad and Nandakumar (2013) discussed extended life cycle thinking and recyclability analysis to include EOL ship dismantling in the design phase. Jain et al. (2015) stated that the EOL stages are ignored in the design process, despite the fact that $96 \%$ of ships are dismantled in shipbreaking yards with environmental, social and safety issues, leading to serious environmental injustice for the shipbreaking nations. The EOL consequences make it necessary to incorporating ship dismantling into design thinking (Sunaryo and Pahalatua 2015,Jain et al. 2017b). The purpose of design for ship recycling is three fold: reduce or replace hazardous materials, provide an inventory of hazardous materials, and allow for easy dismantling (Sivaprasad and Nandakumar 2013, Jain et al. 2015, Jain et al. 2017a). Following IMOs instruction, some research has already been conducted on replacing asbestos, tri-butyl-tin (TBT) in antifouling paints, and chloro-fluorocarbons (CFCs) in refrigerants (Jain et al. 2015).

\subsubsection{Best Management Practices:}

Given the 20-30 year life span of a ship, the benefits of the "designing for dismantling" approach need to be accompanied by a risk reduction strategy and waste management plan these two areas constitute the management strategy of ship dismantling. To do this, Garmer et 
al. (2015) developed a three step risk assessment method with subsequent validation to ensure that the risk assessment method can be practically applied. The method development is based on a team of yard personnel comprising yard officials, safety and inspection officials, but no involvement of workers. The first step includes preparing ship-specific documents with detailed arrangements of decks, firefighting equipment, logbooks of tank substances, and other pertinent information (Garmer et al. 2015). The second step includes hazardous tasks identification, deployment of safety analysis personnel, and development of inspection/screening tools. Finally, a deeper risk assessment is conducted to advance recommendations for risk minimization. While the process itself is rigorous and provides an important contribution to reducing shipbreaking risks, without involving workers and yard managers, the validation process remains incomplete. The management approach lacks identification of actor characteristics and cost apportionment of the risk adjusted management approach (Hiremath et al. 2016). Life cycle costing (LCC) and social life cycle assessment may be useful for understanding the cost structure (stepwise and define fraction of cost) required to produce a certain level of risk adjusted social benefits.

\subsection{Safety Management:}

A total of 16 publications were identified in this category, with 9 addressing exposure assessment and 6 on working conditions and workers' rights.

\subsubsection{Exposure assessment:}

Workers face three types of occupational risks: occupational hazards with immediate consequences such as accidents and injuries; short-term exposure to hazardous materials via the inhalation of toxic fumes (infecting respiratory systems); and long-term consequences that appear after retiring from dismantling activities. Most of the studies focused on occupational hazards and short-term exposure because the damage is relatively easy to determine and noticeable (Anderson et al. 2001, Hossain et al. 2016).

Hazards-specific exposure assessments have been conducted in several areas: asbestosis (Courtice et al. 2011, Wu et al. 2015), lead exposure (Goldberg et al. 1963, Maccallum et al. 1968, Tola and Karskela 1976, Nosal et al. 1990), paint exposure (Engstrom et al. 1990), metal exposure during cutting (Ho et al. 1989), and long term mortality among shipbreaking workers in Taiwan (Liu et al. 2003, Wu et al. 2013). In Bangladesh, 87\% of the shipbreakers were not aware what "asbestos" was and $41 \%$ did not recognize photographs of it (Tola and Karskela 1976).

Metal cutting activities dominate $71 \%$ of the total labor force. These activities pose risks to cutters and helpers due to inhalation of fumes released during cutting (Deshpande et al. 2013, Rahman et al. 2016). The connection between asbestos exposure and cancer detection was also studied on 4427 shipbreaking workers in Taiwan from 1985-2008, and the authors recommended continuous monitoring of workers for early detection of asbestosis and cancer (Wu et al. 2013, 2015). Liu et al. (2003) provided information regarding exposure-induced mortality rates and externally caused mortality in Taiwan through a 13 year retrospective study. Symptoms develop over time and thus require continuous health surveillance throughout a worker's life (Ho et al. 1989). 
The exposure assessment studies summarize the exposure of heavy metals, exposure to occupational hazards and differences of exposure in terms of distances, times and type of work/workers, with some retrospective references to the long-term impacts on worker health and mortality. It is noteworthy that similar studies have not been conducted in the current shipbreaking nations (except Deshpande et al. 2012 and Courtice et al. 2011), signaling a critical gap in our understanding of impacts on workers' long-term health in developing countries.

\subsubsection{Working conditions:}

Working conditions and worker rights mostly revolve around medical facilities, safety equipment, and accidents and injuries management (Anderson 2001, Bianchi 2005, Sahu 2014). Our review revealed an observed disparity in conditions and rights across the three largest shipbreaking nations. The Gadhani shipbreaking yard in Pakistan provides safety equipment and emergency medical care while India and Bangladesh devolve responsibility to the workers (Iqbal and Heideggar 2013, Sahu 2014). Gadhani shipbreaking surpasses India and Bangladesh in terms of application of heavy machinery, the existence and functioning of labor unions, and compensation enforcement for accidents and injuries. With no report of child labor, no night shifts with less overtime, higher wages, and strong inspection teams, the Gadhani yard represents a higher social responsibility to workers and working conditions. However, issues such as lower use of protective equipment, awareness of asbestos removal, training for workers, health screening, the contractual nature of employment, and causes of deaths and injuries remain comparable to India and Bangladesh (Iftikhar et al. 2016). It is common practice for these three Asian nations to sell asbestos to local communities, demonstrating the low awareness of its dangers (Ahmed and Siddiqui 2013). Another common theme of this working conditions literature is the lack of proper documentation of accidents and their consequences for the workers.

While poor working conditions have dominated conversations about shipbreaking from NGOs, few peer-reviewed research has been conducted on the specificities of the workers engaged in this risky industry, indicating an urgency of a social life cycle assessment across different scales (Tiwary et al. 2008). This will provide interesting comparability among shipbreaking nations and identify critical areas of improvement. It is also noteworthy that except for general discussions of working conditions in the sub-standard yards, we still lack information that relates these risks to workers' long-term wellbeing.

\subsection{Social, cultural and policy aspects:}

Studies in this broad area have focused on environmental justice, policy challenges, and economic issues such as capacity building, marketing, cost-benefit analysis, and recycling chains. Among these, capacity building mechanisms and funding requirements emerged as key conditions that can reduce shipbreaking's adverse impacts (Rahman and Kim 2020, Rahman and Mayer 2016). While economic drivers are highly important in the sustainability of shipbreaking industry, it is very important to make economics as a separate analytical discipline. However, in this paper, due to a few papers that fall in economic discipline, we have analyzed within social science category. In the next category where we will discuss the 
dimension as a sustainable dimension, we will regard economic dimensions as one of three important dimensions.

\subsubsection{Environmental Justice:}

Justice framing of shipbreaking issues was well addressed. Most studies mentioned poor working conditions, lax environmental regulations, and economic incentives for toxic dumping in developing countries. Environmental justice was considered from multiple perspectives and scales: world system (Frey et al. 2013), north-south value conflict (Cairns 2007), socio-economic compulsion (Gregson et al. 2012, Cairns 2014), ecological distribution conflicts (Demaria 2010), and tension between NIMBY vs WIMBY (Sonak et al. 2008). For example, Demaria (2010) suggested that it is a WIMBY (Welcome Into My Backyard) phenomenon, posing challenges to Western notions of justice. Gregson et al. (2016) showed that strict enforcement of toxic bans might lead to the movement of peripheral workers to the toxic activities in core countries, as seen with the migration of Eastern European laborers to Western European recycling facilities. Socio-economic compulsion along with lack of institutional capacity pose challenges to ensure justice from developing country perspectives.

\subsubsection{Policy challenges:}

The Basel Convention and the Hong Kong International Convention on the Safe and Environmentally Sound Recycling (HKC) are important policies that regulate the shipbreaking industry, along with the latest European Ship Recycling Regulations (ESRR). Policy publications mostly focused on national and international policy gaps and challenges for improvement of the industry (Alam and Faruque 2014, Zhang and Chang 2014, Rahman and Mayer 2016, Alcaidea et al 2016), technical and financial incentive structures (Rahman and Mayer 2016), and international regulatory loopholes (Alcaidea et al. 2016). These regulations mostly focus on "polluter pays principals", "proximity principals" and "extended producer responsibility". The ESRR forbids EU ships from being dismantled in substandard yards, as per proximity principals and guided by the Basel Convention. The HKC provides detailed procedural guidelines, from dismantling decisions by shipowners to dismantling ships in yards, through the deployment of proper documentation, certification and inspections (Karim 2014, Rahman and Mayer 2016, Alcaidea et al. 2016).

Practices of selling ships for dismantling are not well regulated: loopholes exist which allow owners to reflag EOL ships before beaching, relaxing ship owner responsibilities and boosting their profit margin (Saraf et al. 2010, Alcaidea et al. 2016). These loopholes and perverse economic incentives need to be addressed (Schoyen et al. 2017). The economic incentives of the ship-owners for substandard recycling facilities and strong demand for metal scraps in the recipient countries reinforce lax regulations that come at the cost of worker safety (Rahman and Mayer 2016, Cairns 2014).

Another important issue is the difference in commitment to regulations of international policy institutions and the implementing nation state (Alam and Faruque 2014). Given the consequences of the strict enforcement of international regulations (e.g., leakage effect, lack of enforcement of polluter pay principals), national policies often only superficially respond 
to improvement mechanisms (Rahman and Mayer 2016). While there are several causes and factors that prevent nation states from enforcing laws, the extent to which the national level regulators influence the existing working conditions and tolerate pollution levels is still unknown (Garud 2012). A national/ global level LCSA study should identify to what extent the lack of suitable international policies allows yardowners to maintain the status quo.

The noteworthy concept of technical and funding assistance stipulated in the HKC was mentioned in most of the publications in this category, but there is not a single paper which focuses on that as a main concept to formulate guidelines for assistance. This is another critical research need.

\subsubsection{Cultural aspects of recycling networks:}

Gregson and colleagues $(2011,2013)$ developed a strong argument, drawing from economic and cultural geography, which shapes an innovative perception of shipbreaking practices. According Gregson et al. (2011), the resource recovery activities epitomize a corporeal vulnerability that disregards space and time - be it in developing countries or developed countries (Gregson et al. 2011, 2014). The microscale activities represent "dirty" work capable of attracting migrants and the underprivileged, creating spatial injustice (Gregson et al. 2014).

Hazardous waste is often culturally contingent (Gregson et al. 2011). In the context of developing countries, the ship-scrapped materials (glass wool, asbestoses, black paint oil and furniture) are used by lower and middle classes in South Asia (Gregson et al. 2010a, Gregson et al. 2012, Gregson et al. 2013 and Crang et al 2013). For example, the formation of the secondary processing industry across Bangladesh and consumption of EOL consumer products indicates a cultural inclination that is intricately bound with the global flow of waste, a symbiotic relationship that spans local to global scales.

A social life cycle study is thus important to quantify how the processing of so-called "waste" endangers and/or uplifts a recycling society through the consideration of local, social, cultural and individual preferences and expectations.

\subsection{Economics of shipbreaking:}

There were only six papers with economics as a main content of analysis. The studies mostly discussed disposal decisions of shipowners (Knapp 2008, Kagkarakis et al. 2016), economic feasibility of ship dismantling in developed countries (Mackenny 1994, Choi et al 2016), funding estimates for yard capacity development of the south Asian countries (Yujuico 2014, Rahman and Mayer 2016) and dwindling competitiveness of Chinese yards (Du et al. 2017). Choi (2016) provided interesting information about the cost of the standard recycling method of ships in the US, and found that the decision to recycle ships in developed countries can be profitable, in addition to the benefits derived through the production of metal scrap. Yujuico (2014) described the need to apply the "polluter pays principle", and estimated about 53.5 million USD would be needed to upgrade Bangladesh shipbreaking capabilities (as well as 43 M USD for Gadhani, Pakistan). His analysis incorporated the needs for developmentally appropriate aid and good governance, supported by strong international policies. The Chinese shipbreaking market has been shrinking despite its satisfactory safety management and higher environmental standards setting (Du et al. 2017). The increasing investment costs in greener facilities require government monetary incentives (subsidies) and other trade supports in order 
to remain competitive, as is the case for China (Du et al. 2017). This demonstrates a strong need to employ Life Cycle Costing (LCC) in the shipbreaking industry in order to understand complex dynamics such as cost vs competitiveness.

\section{Discussion:}

\subsection{Strengths of the shipbreaking literature:}

The literature on environmental dimensions demonstrated that shipbreaking activities discharge pollutants to coastal ecosystems, and aimed to highlight environmental impacts for policy makers at national and international levels. All shipbreaking nations have conducted environmental pollution research to identify sources of pollutants, with varying levels of precision (Aydin et al. 2014, Kara et al. 2014), and impact assessments (such as life cycle assessment) at the process level (Rahman et al. 2016, Despande et al. 2013). In addition, recent efforts to identify waste content inside EOL ships signifies a shift to more detailed environmental data that can be used to formulate more effective policies (Jain et al. 2016, Hiremath et al. 2015).

Although workers' issues are rarely investigated in detail, most of the publications touched upon the aspects of working conditions, often using an environmental justice frame or an employment opportunities frame. Long term occupational exposure was studied only in Taiwan, establishing exposure impact on worker health and wellbeing during employment and afterwards. Worker safety indicators and implementation were typically discussed without developing consistent social indicators and their impacts across scales (for example families, self-health conditions, wellbeing) and without referring to critical trade-offs in areas such as economic investment required, cultural contagiousness, risk or cost versus benefits for workers (short- and long-term). Deeply understanding these critical issues requires innovative, interdisciplinary methodologies.

Economic analyses are rare, although they are discussed in general terms in most of the publications. Scrap price variability and market conditions, which determine ship-owners' decisions whether and where to discarding ships, have been studied as stand-alone issues (Knapp et al. 2008, Kagkarakis et al. 2016). There is still a need to generate cost information with business competitiveness, social variables and environmental indicators. More critical research should explore stage-wise cost distributions at national and international levels, to resolve issues related to ship-owners decision criteria at the point of selling ships for dismantling, and tradeoffs between economic and sustainability considerations (Choi et al. 2016, Welaya et al. 2012).

\subsection{Shortcomings of the existing research:}

\section{- Environmental impacts beyond pollutant assessment}

The environmental impacts of shipbreaking have been reduced to pollution impacts. There is some recognition that the pollution assessment research is incomplete; there is a need for better identification of all sources of pollutants (Neser et al. 2008). According to this review, pollution apportionment research has only been conducted in Turkey and India (Aydin et al. 2014). More research is needed on direct ship-based waste quantification, and life cycle assessment to identify impacts of those pollutants on human health and ecosystems. 


\section{- Institutional conditions that can promote fair working conditions are neglected}

Institutional and policy setting is highly specific to country context. Therefore, it is important to understand how (and to what extent) socio-political context can impede policy and regulatory improvements. This knowledge is key to developing better policies at multiple scales, and understanding interactions across scales.

- An interdisciplinary approach is missing.

The shipbreaking literature predominately covers environmental and social issues from a single discipline approach. Few studies have addressed environmental, social and safety issues together in a holistic framework. For example, Neser et al. (2008) and Devault et al. (2016) generally discussed the environmental, social and safety issues but did not incorporate economic aspects such as cost distribution or funding mechanisms for regulatory enforcement.

\section{Proposed LCSA methods in SBI research:}

\subsection{System integration:}

It is evident so far that shipbreaking research represents conventional disciplinary boundaries and ignores synergistic interactions, conflicting social goals and trade-offs (Liu et al. 2015). System integration enables coupling of human and ecological systems in order to understand system complexity and enhance synergies among factors (Liu et al. 2015). Shipbreaking generates impacts across scales (local, national and global), dimensions and organizational levels. For example, asbestos use threatens yard workers (local impact) but adds to local secondary business including yard owners' income (economic dimension) and reduces environmental waste production (environmental dimension). The business culture, in turn, supports the persistence of EOL ship trade in the international market (global impact). Improving yards is not a goal in itself. For example, facility improvement in China reduced overall business competiveness, resulting in net negative impacts through leakage effects, which in turn influenced yard owners' decisions in other countries (Du et al. 2017). Shipbreaking income provides economic security but may reduce family solidarity through labor migration and threatens health through exposure to occupational hazards (Figure 9). 


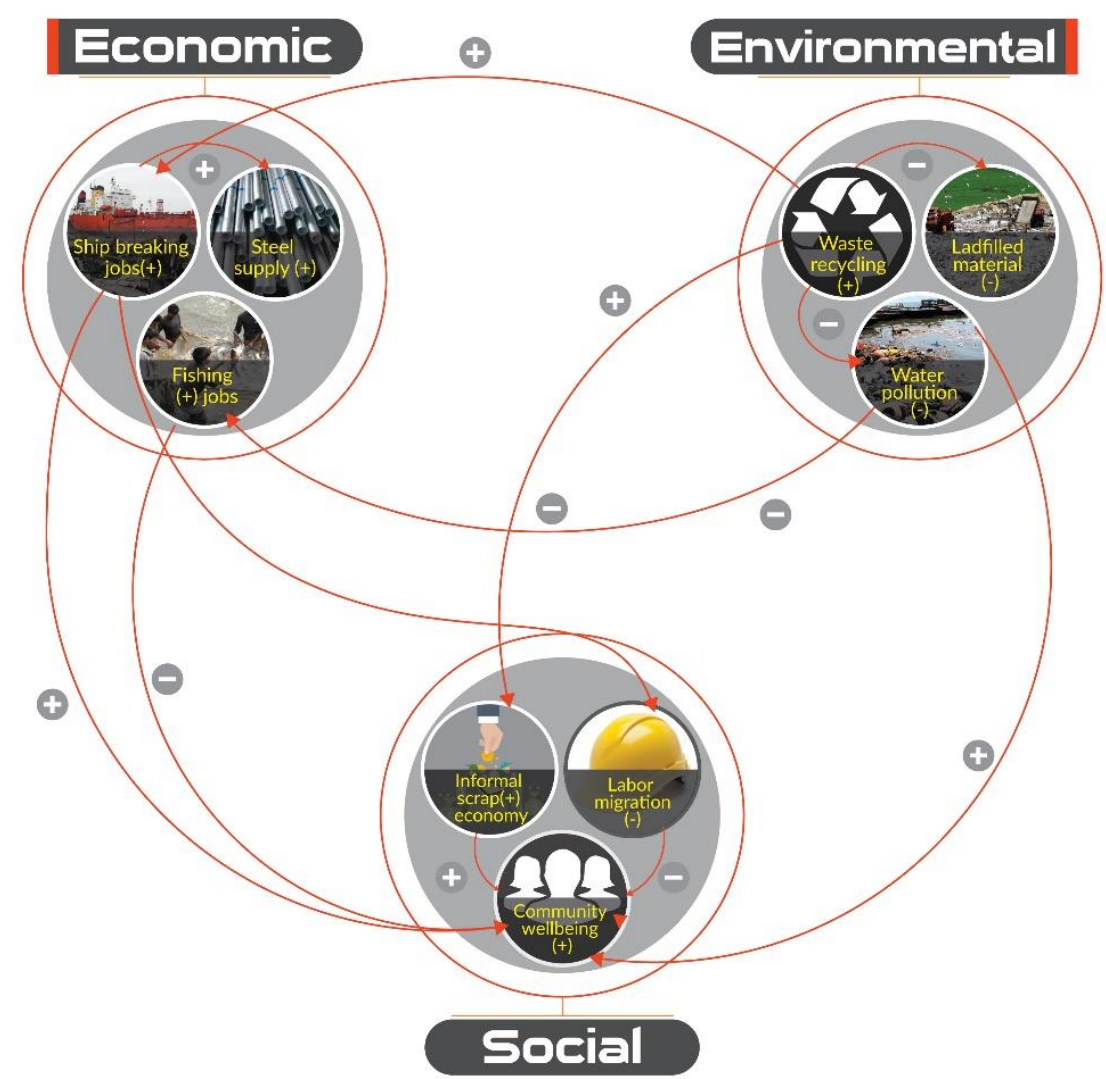

329 Figure 9: Interaction trajectories among shipbreaking variables at the national level; $(+) /(-)$ 330 inside the parenthesis () represents the nature of the variables; $+/$ - inside the circle alongside 331 the arrow represents synergistic effects.

\subsection{Application of LCSA tool:}

We propose the use of LCSA which combines three dimensions following four essential steps: Goal and scope definition, inventory analysis, life cycle impact assessment and interpretation. The approach depends upon compatible system boundaries and functional units, not just co-publishing the three dimensional evaluation scores together. Until recently, ELCA was applied in many product systems with less application of LCC and SLCA. Thus, the sustainability estimation lacks the understanding of the triple bottom line approach. Currently, product system research emphasizes the combination of those three assessment tools, called LCSA. LCSA can be represented by the following equation:

$$
\mathrm{LCSA}=\mathrm{ELCA}+\mathrm{LCC}+\mathrm{SLCA}
$$


This approach seeks to measure/evaluate interdependent effects using a systemic approach, and to allow for the estimation of trade-offs in improvement across dimensions (e.g., the economic cost of increased standards for worker safety and environmental protection against the profit margin of the yardowners) (Traverso et al. 2012). However, Kleopffer (2008) maintains that separate assessment of the three dimensions can still be compared if they utilize the same system boundary. As shipbreaking is a new field of LCSA evaluation, flexibility in terms of separate individualized assessment can be a first step for evaluation because the collection and preparation of data for each step are usually difficult to obtain.

Inventory analysis - an obligatory step in LCSA standardised by ISO 14040-14044 (e LCA), offers yard-level data with associated trade-off information that can facilitate critical policy analysis. Environmental LCA quantifies hazards and environmental impacts caused by the release of toxic contaminants with its limitations for high data collection times, resources and lack of availability of appropriate data (Rahman et al. 2016). LCC examines the cost structure from environmental and industrial perspectives of different stages of the product life cycle, identifying the viability of stages (brokering in international zones) and profitability to stakeholders (Figure 10). Finally, SLCA evaluates the social wellbeing of stakeholders such as workers, local communities, evaluates socio-economic development, and identifies organizational behaviour such as company negligence, policy gaps, and institutional weaknesses (Weidema 2006, Drayer et al. 2010). The sustainability score from each of these assessments can be communicated together in a sustainability dashboard exemplified in Finkbeiner et al. (2010) and Traverso et al. (2012). The dashboard displaying sustainability status can be compared among the shipbreaking nations, using data inventory to compare among inventories at the yard level (such as yard level cost data, profit level, waste discharge and exposure, safety cost and inspection arrangements).

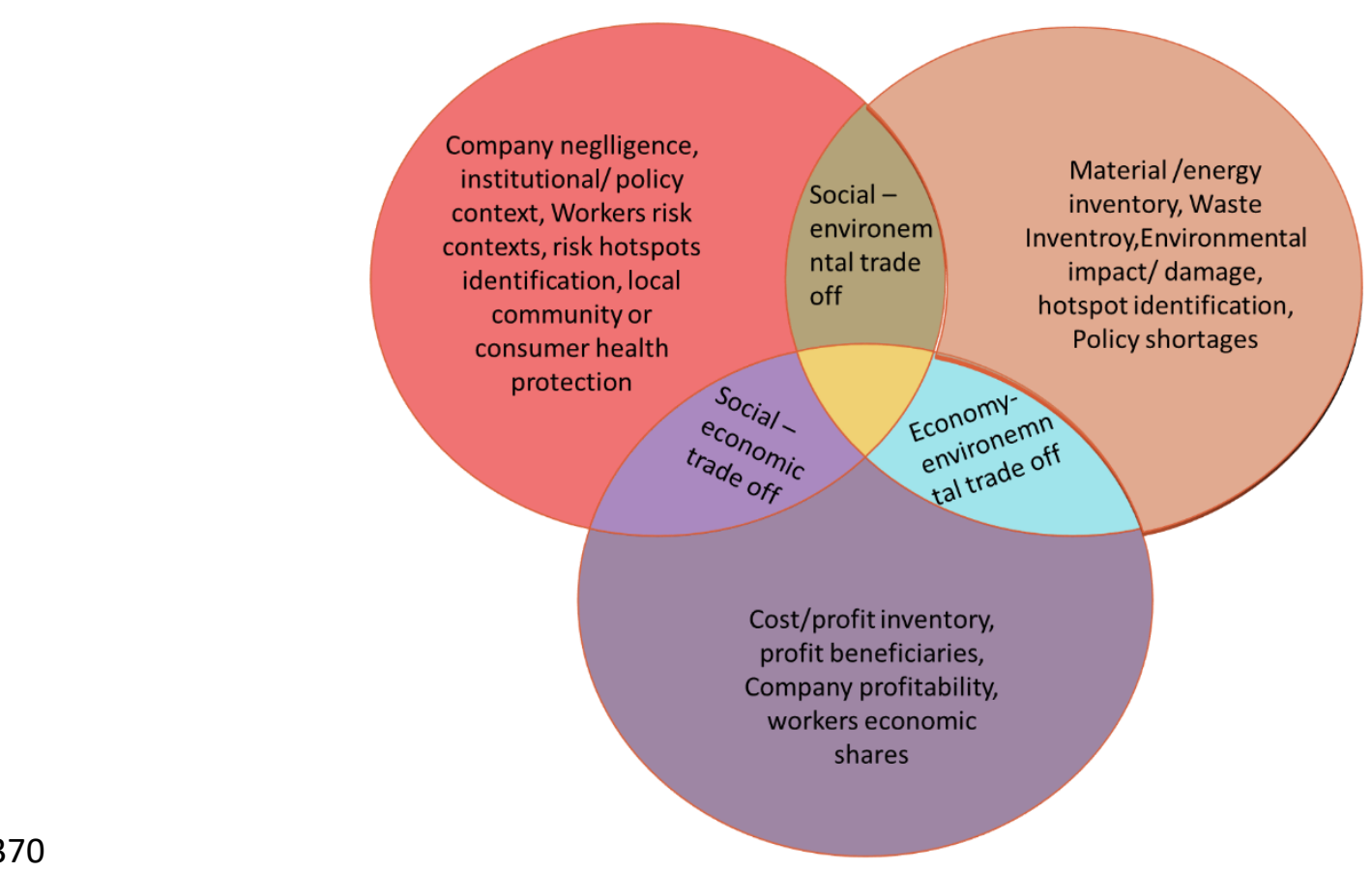


Figure 10: Potentials of Life Cycle Assessments for resolving shipbreaking issues

In addition, individual case studies can also provide important national-scale/ yard scale data and allow for improved policy analysis. For example, yard officials can document environmental, social and economic data, and the results might be used to negotiate with a government for policy support and enhancing competitiveness, and international organizations for eliciting ship-owner compliance. National level studies can apply LCSA to obtain yard level compliance and direct funding incentives from international organizations. LCSA is not without its limitations: for example, SLCA is still not standardized and require subjective assumptions. In addition, there are some issues that LCSA cannot improve, such as the flag state problem. However, this approach will systematically approach towards the conflicting social, economic and environmental goals and offer a baseline information for trade offs to inform sound policy making.

\section{Conclusion:}

The current collection of research covers a few areas very deeply, but leaves many gaps within and across disciplines. The papers reviewed here do establish the pollution potential of shipbreaking, but more rigorous studies are required to address source apportionment issues, ship-wise waste content, designing ships with less hazardous materials and easy dismantling techniques, cost distribution and profit sharing, and workers income versus health risks. Better detail on these points can support rigorous policy initiatives, such as schemes of financial assistance for improvements of shipbreaking yards (Rahman and Mayer 2016). Indeed, economic considerations are often prioritized over environmental and social dimension of sustainability. However, as economic development occurs, environmental and social issues begin to take precedence, as noticed in the migration of shipbreaking activities to south Asian nations. For this reason, shipbreaking sustainability depends upon a clear understanding of trade off criteria among economic, social and environmental factors. The introduction of stricter regulations for improving environmental and working conditions may not be immediately effective given the continuous pursuit for profit that drives dismantling across borders, leading to worse performance and policy failure. In addition, the projects such as IMO-SENSREC project should utilize LCSA methodological tools for sound estimation of sustainability issues. We hope this review spurs new research towards complicated issues that cut across sustainability dimensions.

\section{References:}

Abdullah, H. M., Mahboob, M. G., Banu, M. R., \& Seker, D. Z., 2013. Monitoring the drastic growth of ship breaking yards in Sitakunda: a threat to the coastal environment of Bangladesh. Environmental monitoring and assessment. 185(5), 3839-3851.

Ahmed, R., \& Siddiqui, K., 2013. Ship breaking industry in Pakistan- problems and prospects. International Journal of Management. IT and Engineering. 3(9), 140.

Aktaruzzaman, M., Chowdhury, M. A. Z., Fardous, Z., Alam, M. K., Hossain, M. S., \& Fakhruddin, A. N. M., 2014. Ecological risk posed by heavy metals contamination of ship 
breaking yards in Bangladesh. International Journal of Environmental Research. 8(2), 469-478.

Alam, S., \& Faruque, A., 2014. Legal regulation of the shipbreaking industry in Bangladesh: The international regulatory framework and domestic implementation challenges. Marine Policy. 47, 46-56.

Alcaidea, J. I., Piniella, F., \& Rodríguez-Díaza, E.,2016. The "Mirror Flags": Ship registration in globalised ship breaking industry. Transportation Research Part D: Transport and Environment. 48, 378-392.

Alcaidea, J. I., Rodríguez-Díaz, E., \& Piniella, F., 2017. European policies on ship recycling: A stakeholder survey. Marine Policy. 81, 262-272.

Andersen, A. B., 2001. Worker safety in the ship-breaking industries. International Labour Office, Geneva.

Aydin, Y. M., Kara, M., Dumanoglu, Y., Odabasi, M., \& Elbir, T.,2014. Source apportionment of polycyclic aromatic hydrocarbons (PAHs) and polychlorinated biphenyls (PCBs) in ambient air of an industrial region in Turkey. Atmospheric Environment. 97, 271-285.

Basha, S., Gaur, P. M., Thorat, R. B., Trivedi, R. H., Mukhopadhyay, S. K., Anand, N., ... \& Jha, B., 2007. Heavy metal content of suspended particulate matter at world's largest ship-breaking yard, Alang-Sosiya, India. Water, Air, \& Soil Pollution. 178(1), 373-384.

Cairns, G., 2007. Postcard from Chittagong: wish you were here? critical perspectives on international business. 3(3), 266-279.

Cairns, G., 2014. A critical scenario analysis of end-of-life ship disposal: The "bottom of the pyramid" as opportunity and graveyard. Critical perspectives on international business. 10(3), 172-189.

Carvalho, I. S., Antão, P., \& Soares, C. G., 2011. Modelling of environmental impacts of ship dismantling. Ships and Offshore Structures. 6(1-2), 161-173.

Chang, Y. C., Wang, N., \& Durak, O. S., 2010. Ship recycling and marine pollution. Marine pollution bulletin. 60(9), 1390-1396.

Choi, J. K., Kelley, D., Murphy, S., \& Thangamani, D., 2016. Economic and environmental perspectives of end-of-life ship management. Resources, Conservation and Recycling. 107, 82-91.

Courtice, M. N., Demers, P. A., Takaro, T. K., Vedal, S., Ahmad, S. A., Davies, H. W., \& Siddique, Z., 2011. Asbestos-Related Disease in Banlgadeshi Ship Breakers: A Pilot Study. International journal of occupational and environmental health. 17(2), 144-153.

Crang, M., Hughes, A., Gregson, N., Norris, L., \& Ahamed, F., 2013. Rethinking governance and value in commodity chains through global recycling networks. Transactions of the Institute of British Geographers. 38(1), 12-24. 
Demaria, F., 2010. Shipbreaking at Alang-Sosiya (India): an ecological distribution conflict. Ecological economics. 70(2), 250-260.

Demaria, F., 2016. Can the Poor Resist Capital? Conflicts over 'Accumulation by Contamination'at the Ship Breaking Yard of Alang (India). In: Nature, Economy and Society (pp. 273-304). Springer, India.

Deshpande, P. C., Kalbar, P. P., Tilwankar, A. K., \& Asolekar, S. R., 2013. A novel approach to estimating resource consumption rates and emission factors for ship recycling yards in Alang, India. Journal of Cleaner Production. 59, 251-259.

Deshpande, P. C., Tilwankar, A. K., \& Asolekar, S. R., 2012 . A novel approach to estimating potential maximum heavy metal exposure to ship recycling yard workers in Alang, India. Science of the Total Environment. 438, 304-311.

Devault, D. A., Beilvert, B., \& Winterton, P., 2016. Ship breaking or scuttling? A review of environmental, economic and forensic issues for decision support. Environmental Science and Pollution Research. 1-34.

Dreyer, L. C., Hauschild, M. Z., \& Schierbeck, J., 2010. Characterisation of social impacts in LCA. The International Journal of Life Cycle Assessment.15(3), 247-259.

Du, Z., Zhu, H., Zhou, Q., \& Wong, Y. D., 2017. Challenges and solutions for ship recycling in China. Ocean Engineering. 137, 429-439.

Du, Z. F., 2012. The Safe and Environmentally Sound Recycling of Ships and its Application in China. Advanced Materials Research. 490, 2704-2708

Du, Z. F., Wang, H., Xu, H., Li, C., Yan, H. S., Xu, H. L., ... \& Li, H. W., 2012. Discussion on Control of Hazardous Materials in Ship Recycling Activities. In: Advanced Materials Research (Vol. 476, pp. 1674-1677). Trans Tech Publications.

Finkbeiner, M., Schau, E. M., Lehmann, A., \& Traverso, M. 2010. Towards life cycle sustainability assessment. Sustainability. 2(10), 3309-3322.

Galley, M., 2014. Shipbreaking: hazards and liabilities. Springer.

Garmer, K., Sjöström, H., Hiremath, A. M., Tilwankar, A. K., Kinigalakis, G., \& Asolekar, S. R., 2015. Development and validation of three-step risk assessment method for ship recycling sector. Safety science. 76, 175-189.

Garud, P. (2012). Incorporation of Global Environmental Norms into Indian Legal Systems: social and economic challenges, with special reference to ship-breaking. Procedia-Social and Behavioral Sciences. 37, 150-156.

Gregson, N., Crang, M., Ahamed, F., Akhter, N., \& Ferdous, R., 2010. Following things of rubbish value: End-of-life ships, 'chock-chocky'furniture and the Bangladeshi middle class consumer. Geoforum. 41(6), 846-854.

Gregson, N., Watkins, H., \& Calestani, M., 2010. Inextinguishable fibres: demolition and the vital materialisms of asbestos. Environment and Planning A. 42(5), 1065-1083. 
Gregson, N., 2011. Performativity, corporeality and the politics of ship disposal. Journal of Cultural Economy. 4(2), 137-156.

Gregson, N., Crang, M., Ahamed, F. U., Akter, N., Ferdous, R., Foisal, S., \& Hudson, R., 2012. Territorial Agglomeration and Industrial Symbiosis: Sitakunda-Bhatiary, Bangladesh, as a Secondary Processing Complex. Economic Geography. 88(1), 37-58.

Gregson, N., Watkins, H., \& Calestani, M., 2013. Political markets: recycling, economization and marketization. Economy and Society. 42(1), 1-25.

Gregson, N., Crang, M., Botticello, J., Calestani, M., \& Krzywoszynska, A., 2016. Doing the 'dirty work' of the green economy: Resource recovery and migrant labour in the EU. European urban and regional studies. 23(4), 541-555.

Habibullah-Al-Mamun, M., Ahmed, M. K., Raknuzzaman, M., Islam, M. S., Negishi, J., Nakamichi, S., ... \& Masunaga, S., 2016. Occurrence and distribution of perfluoroalkyl acids (PFAAs) in surface water and sediment of a tropical coastal area (Bay of Bengal coast, Bangladesh). Science of the Total Environment. 571, 1089-1104.

Hasan, A. B., Kabir, S., Reza, A. S., Zaman, M. N., Ahsan, A., \& Rashid, M., 2013. Enrichment factor and geo-accumulation index of trace metals in sediments of the ship breaking area of Sitakund Upazilla (Bhatiary-Kumira), Chittagong, Bangladesh. Journal of Geochemical Exploration. 125, 130-137.

Hasan, A. B., Kabir, S., Reza, A. S., Zaman, M. N., Ahsan, M. A., Akbor, M. A., \& Rashid, M. M., 2013. Trace metals pollution in seawater and groundwater in the ship breaking area of Sitakund Upazilla, Chittagong, Bangladesh. Marine pollution bulletin. 71(1), 317-324.

Hillier, J., 2009. Assemblages of justice: the 'ghost ships' of Graythorp. International Journal of Urban and Regional Research: 33(3), 640-661.

Hiremath, A. M., Pandey, S. K., \& Asolekar, S. R., 2016. Development of ship-specific recycling plan to improve health safety and environment in ship recycling yards. Journal of Cleaner Production. 116, 279-298.

Hiremath, A. M., Tilwankar, A. K., \& Asolekar, S. R., 2015. Significant steps in ship recycling vis-a-vis wastes generated in a cluster of yards in Alang: a case study. Journal of Cleaner Production. 87, 520-532.

Ho, S. F., Wong, P. H., \& Kwok, S. F., 1989. Study on the health hazards of scrap metal cutters. Headache. 8, 13.

Hossain, M. S., Fakhruddin, A. N. M., Chowdhury, M. A. Z., \& Gan, S. H., 2016. Impact of ship-Breaking activities on the coastal environment of Bangladesh and a management system for its sustainability. Environmental Science \& Policy. 60, 84-94.

Iftikhar, S., Ali, M., \& Nergis, Y., 2016. Risks and Hazards Study of Asbestos in Pakistan. International Journal of Economic and Environment Geology. 6(1), 25-28. 
Islam, K. L., \& Hossain, M. M., 1986. Effect of ship scrapping activities on the soil and sea environment in the coastal area of Chittagong, Bangladesh. Marine Pollution Bulletin. 17(10), 462-463.

Iqbal, K. M. J., \& Heidegger, P., 2013. Pakistan shipbreaking outlook: the way forward for a green ship recycling industry-environmental, health and safety conditions. Sustainable Development Policy Unit and NGO Shipbreaking Platform, Islamabad/Brussels.

Jain, K. P., Pruyn, J. F. J., \& Hopman, J. J., 2015. Influence of ship design on ship recycling. Maritime Technology and Engineering. 269-276.

Jain, K. P., Pruyn, J. F. J., \& Hopman, J. J., 2016. Quantitative assessment of material composition of end-of-life ships using onboard documentation. Resources, Conservation and Recycling. 107, 1-9.

Jain, K. P., Pruyn, J. F. J., \& Hopman, J. J., 2017. Material flow analysis (MFA) as a tool to improve ship recycling. Ocean Engineering. 130, 674-683.

Jain, K. P., Pruyn, J. F. J., \& Hopman, J. J., 2017. Strategic guidance based on the concept of cleaner production to improve the ship recycling industry. Environment Systems and Decisions, 1-11.

Kacar, A., \& Kocyigit, A., 2013. Characterization of heavy metal and antibiotic resistant bacteria isolated from Aliaga Ship Dismantling Zone, Eastern Aegean Sea, Turkey. International Journal of Environmental Research. 7(4), 895-902.

Kagkarakis, N. D., Merikas, A. G., \& Merika, A. (2016). Modelling and forecasting the demolition market in shipping. Maritime Policy \& Management. 43(8), 1021-1035.

Kaiser, M. J., 2008. A review of ship breaking and rig scrapping in the Gulf of Mexico. Ocean Development \& International Law. 39(2), 178-199.

Kara, M., Dumanoğlu, Y., Altıok, H., Elbir, T., Odabası, M., \& Bayram, A., 2014. Spatial distribution and source identification of trace elements in topsoil from heavily industrialized region, Aliaga, Turkey. Environmental monitoring and assessment. 186(10), 6017-6038.

Kara, M., Dumanoglu, Y., Altiok, H., Elbir, T., Odabasi, M., \& Bayram, A., 2015. Spatial variation of trace elements in seawater and sediment samples in a heavily industrialized region. Environmental Earth Sciences. 73(1), 405-421.

Kara, M., Hopke, P. K., Dumanoglu, Y., Altiok, H., Elbir, T., Odabasi, M., \& Bayram, A., 2015. Characterization of PM using multiple site data in a heavily industrialized region of Turkey. Aerosol Air Qual. Res. 15, 11-27.

Karim, M. S., 2015. Prevention of Pollution of the Marine Environment from Vessels. Springer. 
Karlis, T., Polemis, D., \& Georgakis, A., 2016. Ship demolition activity. An evaluation of the effect of currency exchange rates on ship scrap values. SPOUDAI-Journal of Economics and Business. 66(3), 53-70.

Khan, I., Chowdhury, H., Alam, F., \& Kumar, A., 2012. Sustainable design of ship breaking industry in developing countries. Asian Journal of Water, Environment and Pollution. 9(1), 1-11.

Khan, M. A. A., \& Khan, Y. S. A., 2003. Trace metals in littoral sediments from the North east coast of the Bay of Bengal along the ship breaking area, Chittagong, Bangladesh. Journal of Biological Sciences. 3(11), 1050-1057.

Khan, M. Z. H., Hasan, M. R., Khan, M., Aktar, S., \& Fatema, K., 2017. Distribution of Heavy Metals in Surface Sediments of the Bay of Bengal Coast. Journal of toxicology. 2017.

Khandaker, N., 2017. Comment on "Ship Breaking and the Steel Industry in Bangladesh: A Materials Flow Perspective" An Argument for Saving the Baby while Throwing away the Bathwater with Caveat. Journal of Industrial Ecology. 21(1), 204-204.

Kibria, G., Hossain, M. M., Mallick, D., Lau, T. C., \& Wu, R., 2016. Monitoring of metal pollution in waterways across Bangladesh and ecological and public health implications of pollution. Chemosphere. 165, 1-9.

Kloepffer, W., 2008. Life cycle sustainability assessment of products. The International Journal of Life Cycle Assessment. 13(2), 89.

Knapp, S., Kumar, S. N., \& Remijn, A. B., 2008. Econometric analysis of the ship demolition market. Marine Policy. 32(6), 1023-1036.

Ko, N., Gantner, J., \& Wehner, D., 2015. Life cycle assessment of ships with special consideration of ship scrapping. Matériaux \& Techniques. 103(1), 101.

Kurt, R. E., McKenna, S. A., Gunbeyaz, S. A., \& Turan, O., 2017. Investigation of occupational noise exposure in a ship recycling yard. Ocean Engineering. 137, 440-449.

Kusumaningdyah, W., Eunike, A., \& Yuniarti, R.,2013. Modeling tradeoff in ship breaking industry considering sustainability aspects: A system dynamics approach. Procedia Environmental Sciences. 17, 785-794.

Liu, J., Mooney, H., Hull, V., Davis, S. J., Gaskell, J., Hertel, T.,. \& Li, S. 2015. Systems integration for global sustainability. Science. 347(6225), 1258832.

Matz-Lück, N., 2010. Safe and Sound Scrapping of 'Rusty Buckets'? The 2009 Hong Kong Ship Recycling Convention. Review of European Community \& International Environmental Law. 19(1), 95-103.

McCallum, R. I., Sanderson, J. T., \& Richards, A. E., 1968. The lead hazard in shipbreaking: The prevalence of anaemia in burners. Annals of Occupational Hygiene. 11(2), 101-113. 
Mckenney, T., 1994. Feasibility of a Ship Scrapping Yard in Philadelphia. Journal of Ship Production.

Memon, A. A., \& Zarar, M., 2016. Comprehensive Analysis of Existing Infrastructure Conditions Correlating Ship-Breaking Activities and its Implications on Workers and Community a Case Study of Gaddani Town and Ship-Breaking Industry, Baluchistan, Pakistan. American Scientific Research Journal for Engineering, Technology, and Sciences (ASRJETS). 17(1), 245-257.

Mikelis, N. E., 2008. A statistical overview of ship recycling. WMU Journal of Maritime Affairs. 7(1), 227-239.

Misra, H., 2008. Skill and education in income determination: a case study of unorganised workers of Alang. Ind J Lab Econ. 51(4), 949-955.

Misra, H., 2009. Rights of Migrant Labour at the Alang Ship Breaking Yard. Indian Journal of Social Work. 70(3), 487-498.

Moncayo, G. A., 2016. International law on ship recycling and its interface with EU law. Marine pollution bulletin. 109(1), 301-309.

Muhibbullah, M., 2013. Health hazards and risks vulnerability of ship breaking workers: A case study on Sitakunda ship breaking industrial area of Bangladesh. Global Advanced Research Journal of Geography and Regional Planning. 02 (08), 172-184.

Neşer, G., Kontas, A., Ünsalan, D., Altay, O., Darılmaz, E., Uluturhan, E., ... \& Yercan, F., 2012. Polycyclic aromatic and aliphatic hydrocarbons pollution at the coast of Aliağa (Turkey) ship recycling zone. Marine Pollution Bulletin. 64(5), 1055-1059.

Neşer, G., Kontas, A., Ünsalan, D., Uluturhan, E., Altay, O., Darılmaz, E., ... \& Yercan, F., 2012. Heavy metals contamination levels at the Coast of Aliağa (Turkey) ship recycling zone. Marine pollution bulletin. 64(4), 882-887.

Neşer, G., Ünsalan, D., Tekoğul, N., \& Stuer-Lauridsen, F., 2008. The shipbreaking industry in Turkey: environmental, safety and health issues. Journal of cleaner production. 16(3), 350-358.

Nosal, R. M., \& Wilhelm, W. J., 1989. Lead toxicity in the shipbreaking industry: the Ontario experience. Canadian journal of public health. 81(4), 259-262.

Nøst, T. H., Halse, A. K., Randall, S., Borgen, A. R., Schlabach, M., Paul, A., ... \& Breivik, K., 2015. High concentrations of organic contaminants in air from ship breaking activities in Chittagong, Bangladesh. Environmental science \& technology. 49(19), 11372-11380.

Odabasi, M., Ozgunerge Falay, E., Tuna, G., Altiok, H., Kara, M., Dumanoglu, Y., ... \& Elbir, T., 2015. Biomonitoring the spatial and historical variations of persistent organic pollutants (POPs) in an industrial region. Environmental science \& technology. 49(4), 2105-2114. 
633

634

635

636

637

638

639

640

641

642

643

644

645

646

647

648

649

650

651

652

653

654

655

656

657

658

659

660

661

662

663

664

665

666

667

668

Okay, O. S., Ozmen, M., Güngördü, A., Yılmaz, A., Yakan, S. D., Karacık, B., ... \& Schramm, K. W., 2016. Heavy metal pollution in sediments and mussels: assessment by using pollution indices and metallothionein levels. Environmental monitoring and assessment. 188(6), 1-18.

Onat, N. C., Kucukvar, M., Halog, A., \& Cloutier, S., 2017. Systems Thinking for Life Cycle Sustainability Assessment: A Review of Recent Developments, Applications, and Future Perspectives. Sustainability. 9(5), 706.

Patel, V., Jain, S., \& Madamwar, D., 2012. Naphthalene degradation by bacterial consortium (DV-AL) developed from Alang-Sosiya ship breaking yard, Gujarat, India. Bioresource technology. 107, 122-130.

Patel, V., Munot, H., Shah, V., Shouche, Y. S., \& Madamwar, D., 2015. Taxonomic profiling of bacterial community structure from coastal sediment of Alang-Sosiya shipbreaking yard near Bhavnagar, India. Marine pollution bulletin. 101(2), 736-745.

Patel, V., Munot, H., Shouche, Y. S., \& Madamwar, D., 2014. Response of bacterial community structure to seasonal fluctuation and anthropogenic pollution on coastal water of Alang-Sosiya ship breaking yard, Bhavnagar, India. Bioresource technology. 161, 362370.

Patel, V., Patel, J., \& Madamwar, D., 2013. Biodegradation of phenanthrene in bioaugmented microcosm by consortium ASP developed from coastal sediment of AlangSosiya ship breaking yard. Marine pollution bulletin. 74(1), 199-207.

Puthucherril, T. G.,2010. From shipbreaking to sustainable ship recycling: Evolution of a legal regime. Brill.

Radonja, R., \& Jugović, A. (2011). Shipowners' Business Policy in the Context of Development in the Environmental Legislation. Scientific Journal of Maritime Research. 25(2).

Rahman, S. M., \& Mayer, A. L., 2016. Policy compliance recommendations for international shipbreaking treaties for Bangladesh. Marine Policy. 73, 122-129.

Rahman, S. M., Handler, R. M., \& Mayer, A. L., 2016. Life cycle assessment of steel in the ship recycling industry in Bangladesh. Journal of Cleaner Production. 135, 963-971.

Rahman, S. M., \& Mayer, A. L., 2015. How social ties influence metal resource flows in the Bangladesh ship recycling industry. Resources, Conservation and Recycling. 104, 254-264.

Rahman, S. M., \& Kim, J. (2020). Circular economy, proximity, and shipbreaking: A material flow and environmental impact analysis. Journal of Cleaner Production, 120681.

Rahman, S.M.M.; Schelly, C.; Mayer, A.L.; Norman, E.S. Uncovering Discursive Framings of the Bangladesh Shipbreaking Industry. Soc. Sci. 2018, 7, 14. 
669

670

671

672

673

674

675

676

677

678

679

680

681

682

683

684

685

686

687

688

689

690

691

692

693

694

695

696

697

698

699

700

701

702

703

704

705

706

707

Reddy, M. S., Basha, S., Adimurthy, S., \& Ramachandraiah, G., 2006. Description of the small plastics fragments in marine sediments along the Alang-Sosiya ship-breaking yard, India. Estuarine, Coastal and Shelf Science. 68(3), 656-660.

Reddy, M. S., Basha, S., Joshi, H. V., \& Ramachandraiah, G., 2005. Seasonal distribution and contamination levels of total PHCs, PAHs and heavy metals in coastal waters of the Alang-Sosiya ship scrapping yard, Gulf of Cambay, India. Chemosphere. 61(11), 15871593.

Reddy, M. S., Basha, S., Kumar, V. S., Joshi, H. V., \& Ghosh, P. K.,2003 . Quantification and classification of ship scraping waste at Alang-Sosiya, India. Marine pollution bulletin. 46(12), 1609-1614.

Reddy, M. S., Basha, S., Kumar, V. S., Joshi, H. V., \& Ramachandraiah, G., 2004. Distribution, enrichment and accumulation of heavy metals in coastal sediments of Alang-Sosiya ship scrapping yard, India. Marine Pollution Bulletin. 48(11), 1055-1059.

Reddy, N. G. K., 2014. Ship Recycling: An Important Mile Stone for India. Indian Journal of Science and Technology. 7, 15.

Rousmaniere, P., \& Raj, N., 2007. Shipbreaking in the developing world: problems and prospects. International journal of occupational and environmental health. 13(4), 359-368.

Sahu, G., 2014. Workers of Alang-Sosiya. Economic \& Political Weekly. 49(50), 53.

Saraf, M., Stuer-Lauridsen, F., Dyoulgerov, M., Bloch, R., Wingfield, S., \& Watkinson, R., 2010. Ship breaking and recycling industry in Bangladesh and Pakistan. The World Bank, Washington.

Schøyen, H., Burki, U., \& Kurian, S., 2017. Ship-owners' stance to environmental and safety conditions in ship recycling. A case study among Norwegian shipping managers. Case Studies on Transport Policy. https://doi.org/10.1016/j.cstp.2017.06.003.

Seuring, S., \& Müller, M., 2008. From a literature review to a conceptual framework for sustainable supply chain management. Journal of cleaner production. 16(15), 1699-1710.

Shah, B., Jain, K., Patel, N., Pandit, R., Patel, A., Joshi, C. G., \& Madamwar, D., 2015. Draft genome sequence of Paenibacillus sp. strain DMB20, isolated from Alang shipbreaking yard, which harbors genes for xenobiotic degradation. Genome announcements. 3(3), e00554-15.

Sharifuzzaman, S. M., Rahman, H., Ashekuzzaman, S. M., Islam, M. M., Chowdhury, S. R., \& Hossain, M. S. (2016). Heavy metals accumulation in coastal sediments. In: Environmental Remediation Technologies for Metal-Contaminated Soils (pp. 21-42). Springer, Japan.

Siddiquee, N. A., Parween, S., Quddus, M. M. A., \& Barua, P., 2009. Heavy metal pollution in sediments at ship breaking area of Bangladesh. Asian Journal of Water, Environment and Pollution. 6(3), 7-12.

Sivaprasad, K., \& Nandakumar, C. G., 2013. Design for ship recycling. Ships and Offshore Structures. 8(2), 214-223. 
Sonak, S., Sonak, M., \& Giriyan, A., 2008. Shipping hazardous waste: implications for economically developing countries. International Environmental Agreements: Politics, Law and Economics. 8(2), 143-159.

Sujauddin, M., Koide, R., Komatsu, T., Hossain, M. M., Tokoro, C., \& Murakami, S., 2015. Characterization of ship breaking industry in Bangladesh. Journal of Material Cycles and Waste Management. 17(1), 72-83.

Sujauddin, M., Koide, R., Komatsu, T., Hossain, M. M., Tokoro, C., \& Murakami, S., 2017. Ship Breaking and the Steel Industry in Bangladesh: A Material Flow Perspective. Journal of Industrial Ecology. 21(1), 191-203.

Sunaryo, S., \& Pahalatua, D., 2015. Green ship recycle yard design. Journal of Naval Architecture and Marine Engineering. 12(1), 15-20.

Tiwari, R. R., Dave, S. K., Tripathi, S. R., Sathwara, N. G., Majumdar, P. K., Patel, B. D., ... \& Vyas, J. B., 2008. Health Hazards in Ship Breaking Workers of Alang.

Tola, S., \& Karskela, V. (1976). Occupational lead exposure in Finland: V. Shipyards and shipbreaking. Scandinavian journal of work, environment \& health, 31-36.

Traverso, M., Finkbeiner, M., Jørgensen, A., \& Schneider, L., 2012. Life cycle sustainability dashboard. Journal of Industrial Ecology. 16(5), 680-688.

Weidema, B. P., 2006. The integration of economic and social aspects in life cycle impact assessment. The International Journal of Life Cycle Assessment. 11, 89-96.

Welaya, Y. M., Naby, M. M. A., \& Tadros, M. Y., 2012. Technological and economic study of ship recycling in Egypt. International Journal of Naval Architecture and Ocean Engineering. 4(4), 362-373.

Wu, W. T., Lin, Y. J., Li, C. Y., Tsai, P. J., Yang, C. Y., Liou, S. H., \& Wu, T. N. (2015). Cancer attributable to asbestos exposure in shipbreaking workers: a matched-cohort study. PloS one, 10(7), e0133128.

Wu, W. T., Lu, Y. H., Lin, Y. J., Yang, Y. H., Shiue, H. S., Hsu, J. H., ... \& Wu, T. N. (2013). Mortality among shipbreaking workers in Taiwan - a retrospective cohort study from 1985 to 2008. American journal of industrial medicine, 56(6), 701-708.

Yujuico, E., 2014. Demandeur pays: The EU and funding improvements in South Asian ship recycling practices. Transportation Research Part A: Policy and Practice. 67, 340351.

Zhao, Y., \& Chang, Y. C., 2014. A Comparison of Ship-Recycling Legislation Between Chinese Law and the 2009 Hong Kong Convention. Ocean Development \& International Law. 45(1), 53-66. 